\title{
ENTREVISTA A TRINIDAD MORGADES
}

POR

Elisa Rizo

Trinidad Morgades (Santa Isabel, hoy Malabo, 1931), es una personalidad de la cultura en Guinea Ecuatorial. Además de escritora, académica e investigadora, ha desarrollado una larga carrera de impresionantes logros. Morgades es miembro de la Real Academia de la Lengua Española y, entre 2005 y 2010 fungió como Vicerrectora de la Universidad Nacional de Guinea Ecuatorial (U.N.G.E).

Malabo, 17 de marzo del 2010. La siguiente entrevista se inició en la oficina de Doña Trinidad Morgades en la U.N.G.E en Malabo, semanas antes de su jubilación como vicerrectora de tal institución. El diálogo continuó por correo electrónico durante el verano del mismo año.

Elisa Rizo: Quisiera iniciar con una pregunta sobre su famosa obra de teatro, Antígona, misma que es reconocida por los lectores de la literatura guineoecuatoriana no sólo como uno de los puntos de referencia del teatro guineoecuatoriano, sino también como una obra que ofrece una metáfora de Guinea Ecuatorial y su devenir político. ¿Le importaría platicarnos un poco sobre la génesis de esta obra?

TRINIDAD Morgades: Bueno, esta obra tiene que ver con la famosa "marabuntada" política que tuvimos en este país. ${ }^{1}$ Por entonces, unos guineanos de Bioko y Annobón habían sido encarcelados en Bata. Una pariente mía que vivía en Bata vio a los presos chapeando delante de su casa; les trajo agua y cigarrillos. Como resultado de su acción, mi pariente fue encarcelada inmediatamente por este hecho. En referencia a la obra de los dramaturgos griegos, los clásicos siempre me han dado mucho que pensar y muchas veces aplico la realidad de ellos a la realidad de la vida actual. La injusticia actual, de castigar a una persona por socorrer a otra, que para el sistema político de entonces era un delito; eso me hizo aplicar la tragedia de Sófocles a dicho acontecimiento. El ser humano sigue utilizando actitudes negativas en contra de su prójimo, recuerda que

1 Se refiere a la dictadura de Francisco Macías Nguema (1968-1979). 
Creonte prohíbe que Antígona ayude a su hermano. Esa relación entre la realidad y la obra clásica fue mi móvil.

ER: ¿Podría hablarnos más sobre su visión de los clásicos?

TM: Desde que descubrí la importancia que tuvo la cultura griega en la formación de Europa, procuro utilizar las enseñanzas de los escritores griegos en mis obras. Además es un aspecto literario que me divierte mucho. Por ejemplo, tengo en fábrica a Lady Macbeth, que es una señora que conozco y es muy ambiciosa y tengo a Caín y Abel (bíblico) en versión adaptada. Caín y Abel es la historia de dos hermanos. Según la costumbre de una de las etnias de aquí, cuando fallece el padre, el mayor deberá ser educado por la abuela paterna y el menor por la abuela materna. La abuela paterna de Abel tenía mejores medios económicos para educarle, suerte que no tuvo Caín; ya que su abuela vivía en el medio rural. Caín, el menor, jamás pudo perdonar a su hermano Abel, el mayor. Destruyó la vida matrimonial, económica y social de su hermano mayor.

ER: Con referencia a otras literaturas, veo que entre sus estudios se incluyen una Licenciatura en Lenguas Germánicas por la Universidad de Barcelona, y una Tesina sobre la Escenografía y Época de Shakespeare. Es decir, que su visión de las letras es abierta y extensa, va más allá de las letras hispanas. En este sentido, ¿nos puede hablar un poco sobre sus actividades como Presidenta de la Asociación de Profesores y Amigos de la Lengua Inglesa de Guinea Ecuatorial y como miembro de la Real Academia Española de la lengua correspondiente a Guinea Ecuatorial?

TM: Estudié las Lenguas Germánicas (Lengua y Literatura Inglesa), lo que me dio la facultad de dedicarme en la enseñanza de la lengua inglesa. Llegué a mi país después de varios años en España y Europa en diciembre de 1958 y empecé a trabajar en 1959. Desde entonces he tenido una gran demanda para la enseñanza de esta lengua en el país. Y como yo sola no daba abasto, formé una Asociación con el nombre de PROFALINGE (Profesores y Amigos de la Lengua Inglesa) para que los profesores de inglés puedan llevar esa labor.

Enseñar inglés para mí es una fuente de gran aprendizaje, porque me ayuda a mi desarrollo. Siempre procuro que el alumno sepa reflexionar sobre su decisión profesional y su comportamiento social al aprender una lengua. Por otro lado, conocer bien la lengua inglesa ayuda a configurar el Pidgin de Guinea Ecuatorial. Porque a pesar de que nuestros territorios fueron españoles desde 1827, la cultura inglesa fue la base de la cultura criolla. Los ingleses dieron un matiz especial a la occidentalización de Clarence, luego Santa Isabel, hoy Malabo. Por eso hago mis estudios sobre el Pidgin de Guinea Ecuatorial.

En cuanto a la REA (Real Academia Española) fue una grata y agradecida sorpresa que me hicieran la distinción de nombrarme Académica, cuando todavía me falta mucho que hacer para sentirme satisfecha de todo lo que se tiene que hacer y saber respecto a la Lengua Española en este país. Esa nominación me anima de una manera extraordinaria para seguir haciendo cosas a favor de la Lengua Española de Guinea Ecuatorial. El

Revista Iberoamericana, Vol. LXXX, Núms. 248-249, Julio-Diciembre 2014, 1141-1144 
sueño de los hispanistas de este país es convertir a Guinea Ecuatorial en el foco emisor de la Lengua Española en el continente africano y, al mismo tiempo, dar contenido al triángulo hispanolingüístico de España, Iberoamérica y África.

ER: Si me permite, quisiera también preguntarle sobre su actividad profesional en general. Además de ser una autora reconocida, su recorrido profesional ha sido extraordinario: desde la diplomacia hasta el servicio a la comunidad, pasando por la docencia y la investigación.

TM: Todo cuanto he hecho ha sido una cuestión de organización. En la diplomacia, el diplomático era el embajador. El trabajo del diplomático tiene dos partes: una parte política y otra social. Yo, como secretaria hacía la parte técnica y social.

En cuanto al trabajo social, para mí, la Comunidad es el trabajo de extensión universitaria. Un universitario que no aplica sus conocimientos para resolver algunos problemas comunitarios, tiene una asignatura pendiente. El universitario africano no completa sus conocimientos universitarios si no tamiza su cultura social, política, económica del mundo y concretamente de su país.

ER: Entre las muchas actividades a lo largo de su carrera, ¿cuál de sus cargos o proyectos le ha dejado más satisfacciones?

TM: Si se hubiesen cumplido muchos de mis sueños y logros, podría producirme una honra, me iría a la tumba muy satisfecha, pero desgraciadamente "nadie es profeta en su tierra". Por tanto, algunas cosas hechas no han tenido continuidad y muchos sueños han sido rotos. Hay un dicho africano que dice así "Los perros también sueñan, pero nadie lo sabe".

Mi sueño roto, mi ilusión máxima, era dar un carácter más científico a la costumbre de recaudación económica africana de las mujeres llamado "Djangue". Por eso inicié COOPREME (Cooperativa de Ahorro para Mujeres Empresarias). CLUSA, una cooperativa americana: nos apoyó, nos reunió, nos dio una formación cooperativista y conseguimos ahorros muy importantes. Desgraciadamente, no se sabe por qué problemas políticos, la actividad de CLUSA no pudo seguir operando en el país.

Otro sueño fue CANIGE (Comité de Apoyo del Niño Ecuatoguineano) que comenzó cuando la Primera Dama del país tuvo a bien hacerme Vicepresidenta del Comité. Me presenté con apoyo de mujeres muy inteligentes dispuestas para hacer cosas en el país (Jovita Jones, Mª Rosa Vegara, Resurrección Bitá, Agustina, Eulalia, etc.). Efectivamente, hacíamos tómbolas, Reyes Magos, visitas periódicas al hospital, clínicas. Nuestro sueño era hacer una residencia especial para madres en edad escolar y ellas recibirían conocimientos académicos y laborales y tendrían una guardería para sus hijos. Incluso el nombre de CANIGE fue una creación nuestra, pero no sabemos por qué razón me cesaron y mi sueño se quedó sin realizarse.

Otro sueño es la Comisión de Acogida y Seguimiento de Proyectos de Refugiados y Emigrantes Ecuatoguineanos. Esta Comisión era para el proyecto de retorno de los

Revista Iberoamericana, Vol. LXXX, Núms. 248-249, Julio-Diciembre 2014, 1141-1144 ISSN 0034-9631 (Impreso) 
refugiados guineanos, sobre todo para la protección del niño guineano nacido en el extranjero e integrarle en el ámbito lingüístico y cultural de Guinea Ecuatorial. Tener una aldea para el retorno de los refugiados y los fondos que actualmente tiene España y Europa para la construcción de dicho espacio se utilizarían aquí para el desarrollo de la agricultura, ganadería, etc. Los fondos serían manejados por personas que hayan vivido muchos años fuera de Guinea Ecuatorial y saben bien cómo administrar este tipo de economía.

En cuanto a la Red de Mujeres en el Mundo, es un tema que lleva España para la protección y empoderamiento de la mujer africana y de todo el mundo. Este proyecto se asienta en cuatro sectores: educación, política, economía y salud. Pero ahora con la crisis que tiene España, no sabemos si tendrá continuidad.

ER: Le agradezco mucho sus respuestas y la gran labor.

Revista Iberoamericana, Vol. LXXX, Núms. 248-249, Julio-Diciembre 2014, 1141-1144 